\title{
PHYTOCHEMICAL AND PHARMACOLOGICAL POTENTIAL OF ANNONA SPECIES: A REVIEW
}

\author{
AMUDHA P, VANITHA VARADHARAJ* \\ Department of Biochemistry, School of Life Sciences, Vels University, Pallavaram, Chennai, Tamil Nadu, India. \\ Email: vanitha.sls@velsuniv.ac.in
}

Received: 21 February 2017, Revised and Accepted: 17 April 2017

\begin{abstract}
Herbal plants and phytogenic products have used for the treatment of various diseases from ancient times in the folklore medicine worldwide. Crude extracts from plants now play an important and valuable source for natural products that are used in the advancement of medicines against various diseases, for the improvement of pharmaceutical preparations and for novel bioscience research. One such plant genus is Annona, such as Annona muricata, Annona cherimola, Annona reticulata, Annona squamosa, and Annona senegalensis are some species widely cultivating in India and tropical regions of Asia for their edible fruits and medicinal values. These plants have been used for centuries as traditional folk medicine for the treatments of various diseases. The plants are considered to be a good source of vitamins, minerals, plant proteins, fibers, etc., as well as the plant is supposed to have many biological activities. This review describes the morphology and ecology of the plant, its ethnomedicinal uses, pharmacological activities, and phytoconstituents.
\end{abstract}

Keywords: Annona muricata, Annona cherimola, Annona reticulata, Annona squamosa, Annona senegalensis, Phytochemicals and pharmacological properties.

(C) 2017 The Authors. Published by Innovare Academic Sciences Pvt Ltd. This is an open access article under the CC BY license (http://creativecommons. org/licenses/by/4. 0/) DOI: http://dx.doi.org/10.22159/ajpcr.2017.v10i7.18073

\section{INTRODUCTION}

Plants and plant-derived medicinal products have been used to help humankind to continue its healthiness from the dawn of medicine. Over the past century, the phytochemicals in plants play an important role in pharmaceutical discovery. The importance of the active ingredients of plants in medicine has inspiring and denoted scientific interest in the biological activities of these substances [1].

Under the classification of flowering plants, the family Annonaceae also called as custard apple family [2] has many traditional values, mainly composed of trees, shrubs and rarely lianas [3]. The word genus Annona is derived from a Latin word "anon" which means "yearly produce" that specifies the production of fruits to the plants of this family. Under the family Annonaceae, encompassing 2300-2500 species and around 130 genera are currently classified [4]. The family Annonaceae mostly found in tropic regions and few species found in temperate regions also. Around 900 species are Neotropical, 450 species are Afrotropical and some species are Indo-Malayasian.

In the family Annonaceae [5]: Annona, Anonidium, Rolliania, Uvaria, Melodorum, Asimina, and Stelechocarpus are most commonly available and widely distributed generes. In India, the genus Annona is frequently available. Hence, the present review was outlined on some species of Annona from the available literature and depending on the accessible of the plants. The family Annona comprises a number of tropical and subtropical habitats worldwide but its further territorial extension is limited, due to the environmental conditions of the Annonaceae, to geographical areas with very precise characteristics of altitude, temperature, relative humidity, and soil. The most significant species with profitable importance of Annonaceae family including Annona squamosa Linn., Annona reticulata Linn., Annona muricata Linn., Annona senegalensis Linn., and Annona cherimola Linn. were listed in Table 1 and selected for the review.

\section{VERNACULAR NAMES}

\section{A. muricata L.}

A. muricata also known as graviola, guyabano, or soursop in English; asguanabana in Spanish; huanaba in guatemala; zopote de viejas in
Mexico; cabeza de negro in Venezuela; catoche in Argentina; jaca do para in the Netherlands; lakshmanaphal or jangli or mullaraamaphala in India [6]

\section{A. cherimola L.}

A cherimola also known as cherimoya, custard-apple, and cherimoya in English; anonaposhte, cherimolia, cherimoyer, cherimolla, and cherimoya in Spanish; anone, cherimolier, and cherimole in Frensh; cherimoya, cherimolia, cherimoyabaum, and cherimoya in German; grabiola, graveola, and graviola in Portuguese; cherimoa and cherimoya in Japanese; cherimolia, Mexico Pox or poox in Italian; hanuman phal and marytiphal in Hindi; hanuman phalamu in Telugu [6].

\section{A. reticulata $\mathrm{L}$}

A reticulata also known as Jamaican apple, bullock's heart, netted custard apple, and Sweetsop in English; lonang and nona kapri in Malaysia; noinong in Thailand; anonacolorada, anona de seso, anonaroja in Spanish, corossolsauvage, bois cachiman, and cachiman in French; luvun, ramphal, and nona in Hindi [7].

\section{A. squamosa $\mathrm{L}$.}

A squamosa also known as custard apple, sugar apple, and sweet apres in English; sharifa in Hindi; sitaphalam in Telugu; corossolier, cailleux, and pommiercannelle in French [8].

\section{A. senegalensis $\mathrm{L}$.}

A. senegalensis also known as wild custard apple and wild soursop in English; wildesuikerappel in Africa; gishta and gishta gaba in Arabic; pomme cannelle du senegal, annone in French; mchekwa, mkonokono, mtomoko-mwitu, mutopetope, mwitu, mtomoko in Swahili; sinkuongo and jumbukungo in Mandinka.

\section{ECOLOGY}

A. muricata L.

A. muricata found mainly in the humid tropical and subtropical lowlands and common on the coastal areas and slopes. It is commonly seen in the roadsides and also found in pastures and cultivated mainly for the fruit. The species cultivated mainly in home gardens and also 
Table 1: Taxonomic classification of Annona species

\begin{tabular}{lllll}
\hline Binomial name & Annona muricata & Annona cherimola & Annona reticulate & Annona squamosa \\
\hline Order & Magnoliales & Magnoliales & Magnoliales & Magnoliales \\
Family & Annonaceae & Annonaceae & Annonaceae & Annonaceae \\
Genus & Annona & Annona & Annona & Annona \\
Species & Annona muricata & Annona cherimola & Annona reticulata & Annona squamosa \\
Commonono & Annona & Sugar apple \\
\hline
\end{tabular}

found in rural gardens on volcanic and raised limestone islands. They are poor in withstanding frost. A. muricata found throughout the West Indies except in the Bahamas and also occurs from Mexico to Brazil. It is common in the West but infrequent on the southern Florida. It is found in Puerto Rico, mostly on the slopes of Cordillera. A. muricata is native to tropical areas in South and North America and also found in the tropical and subtropical countries such as India, Malaysia, and Nigeria [9].

\section{A. cherimola $\mathrm{L}$}

A. cherimola is mainly found in the highlands from sea-level up to approximately $1400 \mathrm{~m}$ altitude. In Colombia and Ecuador, it occurs naturally at elevations between 1400 and $2000 \mathrm{~m}$ where the temperature ranges lie between 17 and $20^{\circ} \mathrm{C}$ [6]

\section{A. reticulata $\mathrm{L}$}

It is cultivated throughout India up to an altitude of $900 \mathrm{~m}$. It is found growing abundantly and widely in the hilly areas, wastelands, and found in several districts of Andhra Pradesh, Punjab, Rajasthan, Uttar Pradesh, Madhya Pradesh, Bihar, West Bengal, Assam, Gujarat, Maharashtra, Karnataka, Kerala, and Tamil Nadu. It is a native plant of South America and West Indies [10]

\section{A. squamosa L}

It is widely cultivated in India and found in Thailand and originates from the West Indies and South America. A. squamosa is primitive to tropical South America and the West Indies and originated in lowland Central America where it is home-grown, and from there it was distributed to Mexico and throughout tropical America.

\section{A. senegalensis $\mathrm{L}$}

It is widely found in semi-arid to sub-humid all over the parts of Africa. The species occurs along riverbanks, fallow land, and swamp forests and at the coast. Commonly grows as a single plant among the savannah woodlands [11]

\section{BOTANICAL DESCRIPTION}

\section{A. muricata L.}

A. muricata is an evergreen tropical tree and bushy grows up to $9 \mathrm{~m}$ in height. Found in tropical America and Caribbean region of West Indies. Leaves found to be leathery with displeasing odor, broadly elliptic to obovate, $5.8-19.0 \mathrm{~cm} \times 3.7-8.1 \mathrm{~cm}$, and sometimes lightly unequal. Flowering starts during the $3^{\text {rd }}$ year and flowers leaf-opposed on the old wood, greenish yellow, usually three, fleshy, triangular, saccate at the base. Fig. 1 shows the fruit of $A$. muricata and the fruit skin is found to be leathery and covered with curved, soft, pliable spines with white colored pulp inside divided into many segments. Seeds found to be black, oval with smooth finishing surface [7].

\section{A. cherimola $\mathrm{L}$}

A. cherimola is erect but low branched and partially shrubby and it grows up to 5-9 m. Due to the mitriform petiole concealing the bud, leaves are deciduous to semi-deciduous. Leaves are alternate, tworanked, contains hairy petioles; ovate to elliptic, short blunt narrow at the apex; somewhat hairy on the top surface, smooth on the lower surface [12]. Flowers are pleasant, solitary or in group of two or three, on short hairy stalks, have three outer greenish, fleshy, oblong petallike tepals, and three smaller inner tepals. Fruits are syncarp, formed by pistils and receptacle, conical or slightly heart-shaped, $10-20 \mathrm{~cm}$ long

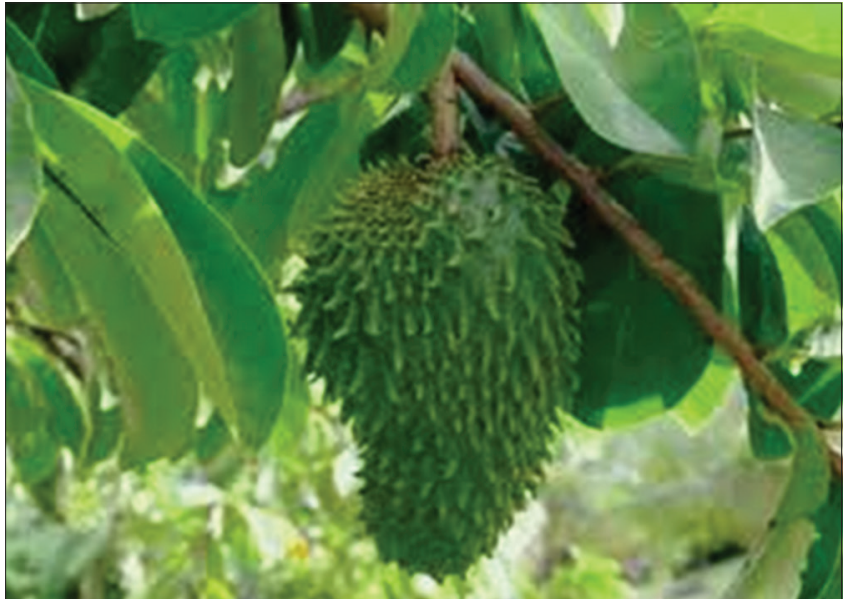

Fig. 1: Fruit of Annona muricata

and up to $10 \mathrm{~cm}$ in width, weighing on average 150-500 g. Skin looks smooth having finger print-like markings and covered with conical or rounded protuberances. Fig. 2 shows the fruit of $A$. cherimola and the fruit is easily broken, exposing snow-white, juicy flesh with pleasing aroma and tasteful, sub acid and contain many hard, brown or black beanlike seeds with $1.25-2 \mathrm{~cm}$ long.

\section{A. reticulata $\mathrm{L}$.}

A. reticulata are small deciduous or semi-deciduous tree grows up to $10 \mathrm{~m}$ height. The bark looks rough, thin and dark brown, $1.4-4.0 \mathrm{~mm}$ thick, and if dried it becomes double quilled. Leaves are found to be oblong, lanceolate, reticulate, pellucid punctate, with bad odor, when young it looks glabrous above and glaucous and pubescent beneath, lateral nerves having 8-11 pairs, petiole grows up to $2 \mathrm{~cm}$ long. Flowers are found to be bisexual, drooping, greenish white, fleshy, solitary, leaf found to be opposite or 2-4 on short extra axillary branchlets. Fig. 3 shows the fruits of $A$. reticulata and the fruit found to be globose, $5-10 \mathrm{~cm}$ in diameter and when ripe it looks yellowish-green color. Berries looks heart-shaped syncarpium with pentagonal areoles, seeds found to be smooth and black in color. The tree has deep penetrating root system with abundant root fibers [7].

\section{A. squamosa L.}

A. squamosa trees are semi evergreen well branched shrub grows up to a height of $7 \mathrm{~m}$. The bark found to be thin, gray, and woody and having extensively branched tap root system. Leaves found to be simple, alternate, oblong lanceolate or elliptic, and pellucid-dotted, peculiarly scented, and $5.0-15.0 \mathrm{~cm} \times 1.9-3.8 \mathrm{~cm}$ in size. Flowers found to be green in color, fleshy, drooping, extra axillary, more on the leafy shoot than on the older wood. Fig. 4 shows the fruit of A. squamosa, and the fruits has many carpels with lozenge shaped on a central torus and fused into an irregular globose or heart-shaped tubercled, yellowish green in color and syncarpium with thick scaly skin. The pulp is sweet and pleasing odor and looks light yellow in color. The seeds found to be oblong and deep brownish black in color and covered with whitish pulp.

\section{A. senegalensis $\mathrm{L}$.}

A. senegalensis is a wild shrub grows up to $7 \mathrm{~m}$, but this plant is not resilient in nature. It is cultivated for its leaves, fruits, flower, bark, and 


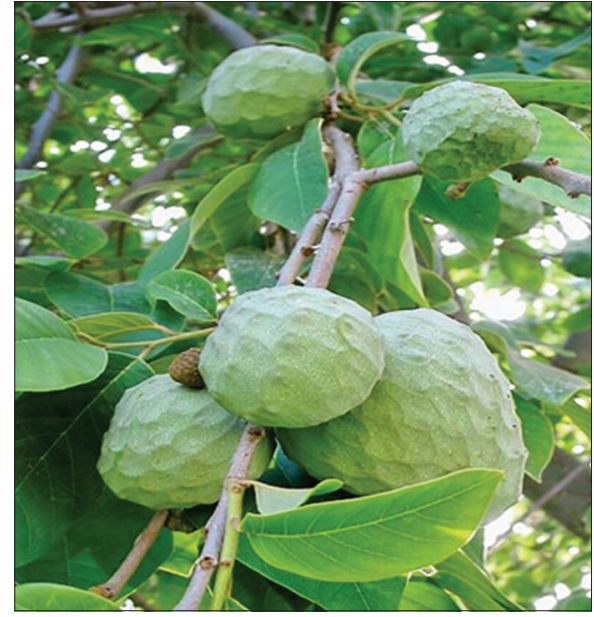

Fig. 2: Fruits of Annona cherimola

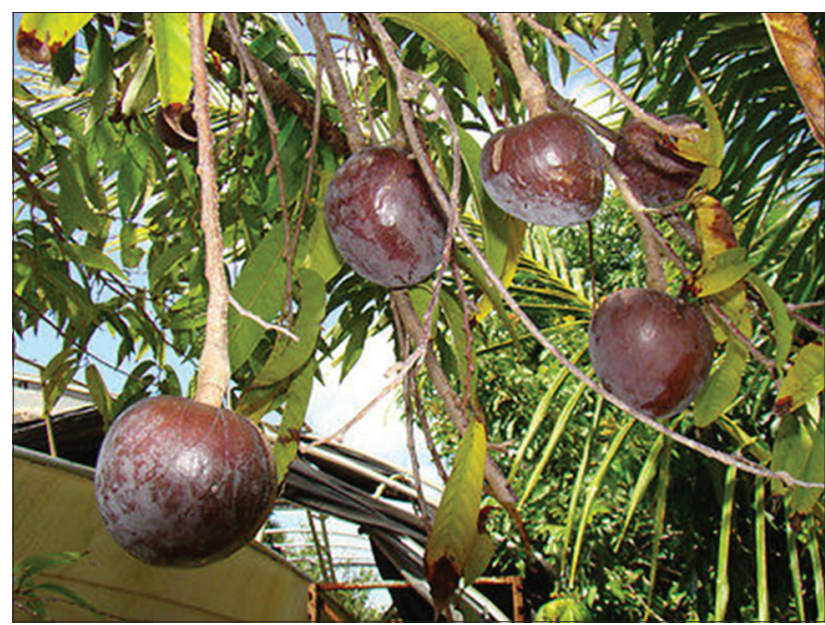

Fig. 3: Fruits of Annona reticulata

stem for medicinal purpose. Leaves are alternate, simple, oblong to ovoid in shape, 6-185 × 25-120 mm in size. The stem looks gray in color when young and smooth to coarsely in older trees. The undeveloped branches have yellow hairs and lost during development. The flowers grows up to $35 \mathrm{~mm}$ in diameter, on stalk grows up to $30 \mathrm{~mm}$ long and directly above the leaf axils. Fig. 5 shows the fruit of $A$. senegalensis and the fruit is formed from several fused and ovate carpels about $45 \mathrm{~mm}$ in diameter. At early stage, it looks dark green and yellow when ripe and finally to orange during the later stage of life. It has a curved inner whorl around the stamens and ovary and with several stamens.

\section{ETHNOMEDICINAL USES}

\section{A. muricata $\mathrm{L}$.}

A. muricata is extensively used as traditional medicines against many human diseases, especially cancer and parasitic infections. The fruit is a good source of natural medicine for arthriticpain, neuralgia, arthritis, diarrhea, dysentery, fever, malaria, parasites, rheumatism, skin rushes, and worms. It is given to elevate mother's milk after childbirth. Leaves are used tocure cystitis, diabetes, headaches, and insomnia. Leaf's decoction is used to treat antirheumatic and neuralgic effects and cooked leaves are used to treat abscesses and rheumatism [13]. Seeds should be crushed can used to treat anthelmintic activities against worms and parasites both internally and externally. A. muricata is used for astringent, insecticide and pesticide and also used to cure coughs, pain and skin diseases in tropical Africa. Fruits and flower are used to cure catarrh and the root-bark and leaves are used to treat antiphlogistic and anthelmintic activities in India [14]. Leaves

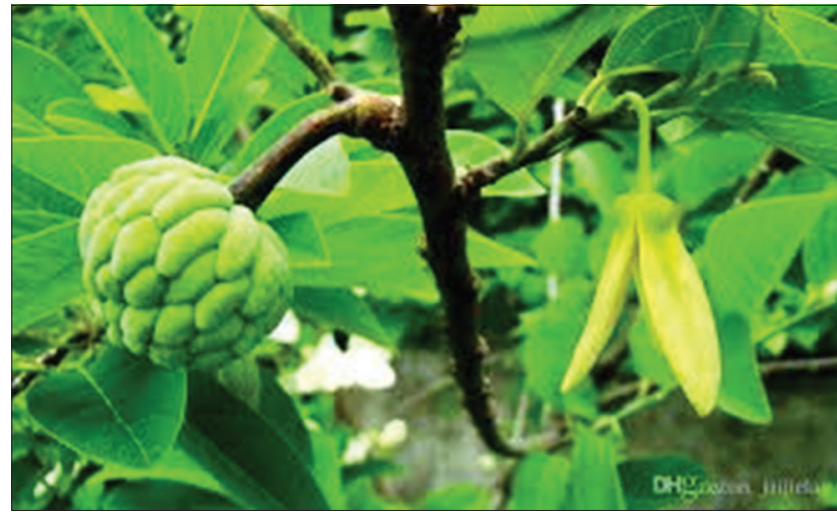

Fig. 4: Fruit of Annona squamosa

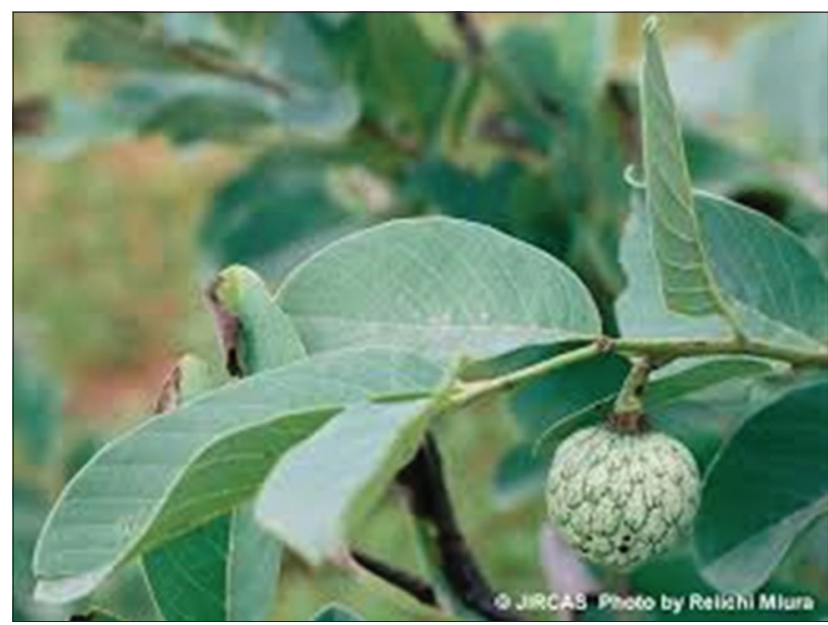

Fig. 5: Fruit of Annona senegalensis

of A. muricata mixed with A. squamosa and Hibiscus rosa-sinensis are applied on the head to protect against fainting in Malaysia. A. muricata leaves are used as an ethnomedicine for tumors and cancer in South America tropical Africa and Nigeria. Leaves, barks, and roots are used to treat the anti-inflammatory, hypoglycemic, sedative, smooth muscle relaxant, hypotensive, and antispasmodic effects.

\section{A. cherimola $\mathrm{L}$.}

A. cherimola is a dessert fruit that can be eaten fresh. Due to its enzymatic characteristics, $A$. cherimola fruits cannot be used for thermal processes and its processing should utilize refrigerating or freezing, with addition of antioxidants to avoid enzymatic oxidation and subsequent coloring [15]. A. cherimola seeds are used as an insecticide to kill lice and to cure parasitic skin problems. A. cherimola seeds has an important alkaloid, acetogenins [16], which has antiparasitic and cytotoxic activities. The annonaceous acetogenins are a new group of powerful phytochemical agents, and more than 300 of these compounds have been found which has antimicrobial, antitumor, cardiotonic, and insecticidal properties. The fruit contains low cholesterol and sodium. It is rich in dietary fiber, vitamin B6, vitamin C and potassium. Fruit is used traditionally for antimicrobial and insecticidal activities and to cure stomach-ache and pancreatic ulcers. Dried flowers are used as flavoring for snuff in Jamaica. Immature fruit is used for cooked vegetable and bark is used as a decoction for diarrhea. For toothache, root can be chewed and decoction from root can be used to treat fevers. Decoction from leaves can be used to treat worms and leaves are used to tan leather.

\section{A. reticulata $\mathrm{L}$.}

Decoction from bark can be used for the treatment of dysentery and diarrhea. A. reticulata leaves can be used to prepare tea for relieving 
colic. Leaves should be warmed and applied over the abdomen to get relief from indigestion in babies and children in Philippines. Leaves should be crushed can be used as poultice for abscesses and to cure ulcers. Fruits possess antihelmintic properties. Root bark is used to cure toothache and is placed around the gums to get relief from toothache and decoction from roots can be used to cure fever. Decoction from leaves can be used in treating malaria and syphilis. The roots can be used for epilepsy. A. reticulata has been used as an anti-inflammatory agent, antianxiety, antistress, antimutagenic, and spasmolytic agent. Leaf and stem extract possess inotropic, positive for chronotropic and spasmolytic properties [6].

\section{A. squamosa L.}

A. squamosa has lots of medicinal values. Unripe fruit can be used as an astringent and root can be used for drastic purgative and seeds can be used to treat antifertility activity. Leaves can be used as a vermicide, for treating tumors and applied to abscesses, insect bites and skin problems. For toothache, root and bark scrapings can be used. Seeds should be powdered can be used to kill head-lice and fleas and proper care should be taken to avoid the powder to come in contact with eyes since it causes severe pain. Fruits, seeds, and leaves possess vermicidal and insecticidal properties. Pulp can be used as a flavoring agent in ice creams. Between $50 \%$ and $80 \%$ of the fruit are edible. Since $A$. squamosa has the biochemical substances such as alkaloids, glycosides, resins, volatile oils, gums and Tannins and ascorbic acid the plant possess excellent medicinal properties [17]. A. squamosa contains more of vitamin C (35-42 mg/100 g) than in grapefruit. The nutrient value of thiamine, potassium, and dietary fiber is also found to be higher.

\section{A. senegalensis $\mathrm{L}$.}

A. senegalensis has an excellent source for traditional medicine applications. Leaves can be used for treating yellow fever, tuberculosis, and small pox and stem bark can be used for snakebite and hernia treatment [18]. Root can be used for difficulty in swallowing, gastritis, snake bites, male sexual impotence, erectile dysfunction, tuberculosis, and as an antidote and root bark can be used for infectious diseases [19]. Juice can be collected from the tree can be used for the treatment of chicken pox [20]. Many parts of the plant can be used as antidotes for venomous bites and management of diabetes [21]. A. senegalensis has been used for treatment of malaria in Guinea [22], and bark can be used to cure open sores in Switzerland [23]. A. senegalensis a long with Ageratum conyzoides can be used for diarrhea and with Nauclea latifolia used for dysentery practiced in the Benue state in North Central Nigeria [24]. Fresh leaves can be used in poultry houses and left until they dry and the process can be repeated once or twice a week for controlling parasites including fleas and lice in Nigeria and Tanzania [25]. A. senegalensis can also been used as food and food additives. Leaves can be used as vegetables and edible pulp of the fruit has a pleasant taste and the flowers can be used as spices for various foods.

\section{PHYTOCHEMISTRY}

\section{A. muricata L}

A. muricata contains carbohydrates, phenols, flavonoids, alkaloids, coumarins, glycosies, phytosterols, quinones, steroids, proteins, saponins, and terpenoids. A. muricata contains flavonoids, saponins, tannins, alkaloids, triterpenoids, reducing sugar, and cardiac glycosides in the ethanolic leaf extract [26]. A new acetogenins called cohibins $\mathrm{A}$ and $\mathrm{B}$ and sabadelin which involves in the biosynthesis of monotetrahydrofuran acetogenins were present in the methanolic root extracts and from stem bark a new biogenetic precursor's epoxymurins $A$ and B isolated. From the seed extract, a new monotetrahydrofuran namely murisolin, two new cytotoxic $\gamma$-lactones namely corossolone and corossolin, a newacetogenins, muricatetrocins $A$ and $B$, gigantetrocin $\mathrm{B}$, muricatacin, solamin and epomuricenins $\mathrm{A}$ and $\mathrm{B}$ Annonaceous acetogenins, C-35 and C-37 mono-epoxy unsaturated compounds epomuricenins $\mathrm{A}$ and $\mathrm{B}$, and epomusenins $\mathrm{A}$ and $\mathrm{B}$ and two new mono-epoxy saturated $\mathrm{C}-35$ representatives, epomurinins $\mathrm{A}$ and $\mathrm{B}$ were isolated from fruit pulp of methylene chloride extract.
Annohexocin, annomutacin, annomuricin A to E, annonacinone, corossolone, cis-annonacin, annomontacin, annonacin, epomuricenin $\mathrm{A}$ and $\mathrm{B}$, cis-corossolone, corepoxylone, corepoxylone, annomuricatin A and $\mathrm{B}$, cohibin $\mathrm{A}$ and $\mathrm{D}$, donhexocin, montanacin, muricatetrocin $\mathrm{A}$ and $\mathrm{B}$ muricatin $\mathrm{D}$, annopentocin $\mathrm{A}$ to $\mathrm{C}$, gigantetrocin $\mathrm{A}$ and $\mathrm{B}$, gigantetronenin, goniothalamicin, montecristin, corossolin, gigantetrocinone, isoannonacin, muracin $\mathrm{A}$ to $\mathrm{G}$, muricatalin, muri-catenol, gigantetrocin, murihexocin 3, muricatalicin, muricatocin A to $\mathrm{C}$, muricoreacin, murihexocin A to $\mathrm{C}$, muricapentocin, muricin $\mathrm{H}$, muricin I,rolliniastatin 1 and 2, uvariamicin I and IV, coronin, javoricin, murisolin, solamin, annocatalin, xylomaticin, robustocin, annomonicin and murihexol are the few annonaceous acetogens found in graviola [27].

\section{A. cherimola $\mathrm{L}$.}

A. cherimola has various phytochemicals including alkaloids, flavonoids, glycosides, saponins, tannins, carbohydrates, proteins, compounds, phytosterols, and amino acids. A. cherimola possesses potent antioxidant activity [28]. Stem and seeds possess various chemical constituents includingannocherine A,B, cherianoine, aromin-A,Ncis-caffeoyltyramine, dihydro-feruloyltyramine, N-transferuloylmethoxytyramine, and N-cisferuloyltylmethoxytyramine [29]. Seeds have been found to contain cyclooctapeptieds, cherimolacyclopeptide A, and cherimolacyclopeptide B [30].

\section{A. reticulata $\mathrm{L}$.}

Ethyl acetate, butanol and methanol extract showed the presence of phytochemical components such as alkaloids, tannins, terpenoids, and coumarins [31]. From the leaves contains an alkaloid, tetrahydroisoquinoline which possesses cardiotonic activity and from the bark, a bioactive acetogenin has been isolated. A. reticulata contains aporphine, alkaloids, terpine derivatives, glycoside and a novel diazepine, squamolone [32]. Ethyl acetate extracts of seeds contains 7-1actone acetogenin, cis-/trans-isomurisolenin, along with six known cytotoxic acetogenins, annoreticuin, annoreticuin-9-one, cis-/transbullatacinone, bullatacin, cis-/trans-murisolinone, and squamocin [33] and annoreticuin, bullatacin, squamosine, rolliniastatin [34], reticullacinone, rolliniastatin-2, molvizarin [35], 14-hydroxy-25-deoxyrollinicin [36]. In A. reticulata, by the method of bioactivity-directed fractionation, Bullatacin and a novel bioactive monotetrahydrofuran acetogenin, reticulatacin, and kaurane diterpenes have been isolated from the bark [37]. From the methanol extracts of seeds, two cyclopeptides, the cycloheptapeptide cycloreticulin C, cyclo(Pro ${ }^{1}$ $\mathrm{Gly}^{2}-\mathrm{Gln}^{3}-\mathrm{Pro}^{4}-\mathrm{Pro}^{5}-\mathrm{Tyr}^{6}-\mathrm{Val}^{7}$ ), and the cyclohexapeptide glabrin A, cyclo $\left(\mathrm{Pro}^{1}-\mathrm{Gly}^{2}-\mathrm{Leu}^{3}-\mathrm{Val}^{4}-\mathrm{Il}^{5}-\mathrm{Tyr}^{6}\right)$ have been isolated and sequence and three-dimensional structure of cycloreticulins $\mathrm{A}$ and $\mathrm{B}$, new cyclooctapeptides were also identified [33,34].

\section{A. squamosa $\mathrm{L}$}

A. squamosa possesses glycosides, alkaloids, flavonoids, steroids, phenols, tannins, and saponins in the ethanolic seed extracts. Various phytochemical constituents are isolated from leaves, stem and root were glaucine, norcorydine, aporphine, isocorydine, coryeline, and anonaine. From the leaves anonaine, borneol, camphor, benzyltetrahydroisoquinoline, car-3-ene, camphene, carvone, $\beta$-caryphyllene, farnesol, 16-hetriacontanone, geraniol, hexacontanol, higemamine, limonine, methylheptenone, p-(hydroxybenzyl)-6,7-(2hydroxy,4-hydro) isoquinoline, eugenol, linaloolacetate, isocorydine, menthone, methylsalicylate, methyl anthranilate, n-octacosanol, b-pinene, stigmasterol, a-pinene, $\beta$-sitosterol, rutin, thymol 4-(2-nitroethyl-1)-1-6-((6-o- $\beta$-D-xylopyranosy1- $\beta$-D-glucopyranosyl)-oxy) benzeneandn-triacontanol.Oilextracted fromleaves containgermacrene D, b-elemene, sabinene, aand b-pinenes, bicyclogermacrene, T-cadinol, and T-muurolol are isolated. From fruit oil spathulenol, bornyl acetate, germacreneD, borneol and verbenone were isolated. From stem bark, a new acetogenin squamone were isolated which possesss bullatacin, bullatacinone, liriodenine and (-) kaur-16-en-19-oic acid. From the bark 1Hcycloprop (e) azulene, bisabolene, germacrene D, bisabolene epoxide, kaur-16-ene and caryophyllene oxide were isolated. From the branches liriodenine, moupinamide, annonaine and sachanoic acid 
were isolated. Chloroform extract of the plant possesses Annotemoyin. Annonacin A, annonastatin, saponins like stigma-5,24 (28)-dien-3b-ola-L-rhamnoside, squamostatin A, annonin I, VI, VIII, XIV and XVI. Nearly 30 acetogenins were isolated like squamocins $B$ to $\mathrm{N}$, coumarinoligans, annotemoyin and squamocin, annonastatin, squamocinetc from the seeds. From the roots alkaloids such as liriodenine, oxoanalobine and $\beta$ caryophyllene, $\alpha$-humulene, $\alpha$ pinene, $\alpha$-gurjunene were isolated [38]. Alkaloids, fixed oils, tannins, carbohydrates, and phenols also present in A. squamosa [39].

\section{A. senegalensis $\mathbf{L}$.}

A. senegalensis contains the phytochemicals constituents such as sterols and/or triterpenes, anthocyanes, glucids, coumarins, flavonoids, and alkaloids. From the water and ethanol extract of leaves and roots contains flavonoid, tannis, cardiac glycoside, saponins, alkaloid, steroid, and volatile oils, and negative for saponins, glycoside and antraquinone. The ethanol extract of leaves and root has higher phytochemical activity than compared to the aqueous extract [40]. A. senegalensis found to contain minerals such as $\mathrm{Ca}, \mathrm{K}, \mathrm{Mg}, \mathrm{Zn}, \mathrm{Fe}, \mathrm{Cu}, \mathrm{Mn}, \mathrm{Pb}$, and $\mathrm{Cr}$ as well as ascorbic acid and amino acids, important source of nutrients $[41,42]$. Stem bark contains 1, 2 benzenediol, butylated hydroxytoluene, phenol, 2, 6 bis (1, 1-dimethylethyl-4methyl, methylcarbamate, $\mathrm{n}$ hexadecanoic acid, hexadecane, 13-hexyloxacyclotridec-10-en2one, oleic acid, tetracosane, 9- octylheptadecane, heneicosane, 12-mehtyl-E, E-2, 13-octadecadien-1-ol, octadecanoic acid, 9, 17-octadecandienal, pentadecane, tetratriacontane, and squalene from the GC/MS study [43]. From the root bark, Okoye and coworkers [44] identified diterpenoid, kaur-16-en-19-oic acid or kaurenoic acid as phytochemical constituents responsible for the antibacterial effects. A. senegalensis possess wax, alkaloids [45] proteins, amino acids, antraquinones [46], sterols, glycosides, flavonols, terpenoids [47] and terpenes [48].

\section{PHARMACOLOGICAL STUDIES}

\section{A. muricata L.}

Several studies suggest that flavonoids and phenols are present in A. muricata are free radical scavengers that prevent oxidative cell damage and have strong anticancer activities [49,50]. Due to the presence of redox property and presence of conjugated ring structures and carboxylic group which inhibits lipid peroxidation [51]. The traditional uses such as anticancerous, antidiabetic, antibacterial, antifungal, antimalarial, antimutagenic, emetic, anticonvulsant, sedative, insecticidal, and urine stimulant. It also has antiviral (against Herpes simplex), cardiotonic, digestive stimulant, nerviness, febrifuge, vermifuge, pediculocide, and analgesic properties. The extracts of this plant screened for antiparasitic, astringent, antileishmanial, antidepressant and cytotoxic activities. Aqueous extracts of leaves and seeds show high content of proteins, phenols, non-enzymatic components such as vitamin-C and vitamin-E, enzymatic components such as superoxide dismutase and catalase was having high antioxidant power. Aqueous extracts of $A$. muricata exhibit an antibacterial effect. Methanolic extracts of $A$. muricata shows potent antidiabetic activity by reducing serum total cholesterol, low-density lipoprotein (LDL) and very LDL and a significant increase in high-density lipoprotein and antiatherogenic index [52]. A. muricata leaf ethanol extract has hypoglycemic and hypolipidemic effects [53]. Tannins are useful in preventing cancer as well as treatment of inflamed or ulcerated tissues. Saponins can react with cholesterol-rich membranes of cancer cells; thereby inhibit their growth and viability [54].

\section{A. cherimola L.}

Many pharmacological activities and medicinal applications of A. cherimola are widely known. Various extracts like ethanolic, methanolic, and dimethyl formamide of $A$. cherimola fruits possess concentration dependent free radical scavenging activity. The antidiabetic activity of leaf extract in streptozotocin (STZ) induced hyperglycemia in rats. The leaf extract is responsible for stimulates the insulin release and observed restoration of blood glucose level. The antihyperglycemic activity of the methanolic extract of leaves was comparable with glibenclamide, a standard hypoglycemic drug. The methanolic extract of leaves possesses considerable hypoglycemic activity in normal rats. The leaf extract shows antimicrobial activity against Escherichia coli. Volatile compound (cherimolacyclopeptide E) of this plant was studied for its antimicrobial activity. From the methanolic extracts of the leaves, a pure compound is isolated which exhibits antiviral activity against herpes simplex virus Type 2 viruses. The cytotoxic compounds such as annomolin and annocherimolin were isolated from the seeds, collected in Peru. Annomolin was selectively cytotoxic against the human prostate tumor cell line (PC-3), when compared with adriamycin. Annocherimolin possesses cytotoxic potencies when compared with adriamycin in the breast (MCF-7) and colon (HT-29) cancer cell lines. The effect of ethanolic extracts from leaf was studied on bovine kidney cells (Madin-Darby bovine kidney [MDBK]) and human larynx epidermoid carcinoma cells (Hep-2). The ethanolic extract from leaves possesses significant antitumor activity in vitro against MDBK and Hep-2 cells. Hexane extract of leaves produces antianxiety actions in mice. Methanolic extracted seeds were examined for antiparasitic activity against Entamoeba histolytica, Nippostrongylus brasiliensis, Molinema dessetae, and Artemia salina. The acetogenins isolated from the leaves which inhibit the larvae of $M$. dessetae [55].

\section{A. reticulata $\mathrm{L}$.}

A. reticulata leaf extract shows high activities in quenching 1,1-diphenyl2-picryl-hydrazil and superoxide radicals in plant [56]. Annonaceous acetogenins are a group of phytoconstituents obtained from plants, have potent antineoplastic agents. Acetogenins are efficient cytotoxic inhibitors of the mitochondrial nicotinamide adenine dinucleotide: Ubiquinone oxidoreductase (complex I of the respiratory chain). Seeds of $A$. reticulata contains squamocin which has cytotoxic constituent for mostly all the cancer cell lines tested $[57,58]$. In ethanol extracts, in vitro inhibition toward the vero cell line proliferation was found to be lower when compared with cancer cell lines [59]. A. reticulata leaves show in vitro cytotoxic and human recombinant caspase inhibitory effect [60]. Hence, $A$. reticulata has potent chemopreventive agent in cancer therapy. The aqueous leaf extract has anthelmintic activity [61]. Leaves of A. reticulata can be used in the treatment of inflammatory diseases, and potent new anti-inflammatory agents [62]. Leaves of A. reticulata possess potent glucose lowering effect. The glucose lowering activity is more of corrective in nature than disruptive [63]. By using roots, tea is prepared and used as a treatment for fevers and the bark is used as a powerful astringent for antidysenteric and vermifuge [52].

\section{A. squamosa L.}

Terpenoids, flavonoids, alkaloids, and tannins possess more antioxidant activities that can be used in the treatment of many diseases, including cancer and possess potent antitumor properties [64]. A. squamosa Linn. is used as an antioxidant, antidiabetics, hepatoprotective, cytotoxic activity, gene toxicity, antitumor activity, antilice agent. A. squamosa leaves found to lower considerable fasting plasma glucose level in STZ nicotinamide induced Type 2 diabetic rats in the aqueous extract [65]. A. squamosa contains flavonoids which are responsible for antibacterial activity against bacterial strains [66]. A. squamosa leaf analysed for blood glucose, hemoglobin, glycosylated hemoglobin, plasma insulin, antioxidant enzymes and lipid peroxidation in liver and kidney to STZ-induced diabetic rats. A. squamosa regulates the blood glucose level, increases the plasma insulin, lipid metabolism, and prevents diabetic problems from lipid peroxidation and antioxidant systems in experimental diabetic rats [61]. A. squamosa seeds possess antitumor activity in vivo against AD-5 tumor in the aqueous extracts [67]. A. squamosa extracts have the property of induction of apoptosis for certain types of cancerous cells [68]. A. squamosa bark extracts have anticarcinogenic effect by modulating the status of lipid peroxidation and antioxidants in 7,12-dimethylbenz[a]anthracene painted hamsters [69]. A. squamosa has hepatoprotective activity and could be an effective remedial for chemical-induced hepatic damage [70]. Annona species are potent antimosquito agents [71]. The pure compound annotemoyin-1 isolated from chloroform extract of the seeds of A. squamosa Linn. was tested for its pesticidal activity [72]. In mouse 
Table 2: Pharmacological activities of Annona species - Annona muricata, Annona cherimola, Annona reticulate, Annona squamosa, and Annona senegalensis

\begin{tabular}{ll}
\hline Name of the plant & Pharmacological Activities \\
\hline Annona muricata & $\begin{array}{l}\text { Cytotoxicity and antileishmanial activity, antihyperglycemic activity, diabetes and ß-cell integrity, } \\
\text { hepatoprotective activity, antinociceptive and anti-inflammatory activities, anticancer, antiherpes } \\
\text { simplex virus, antidepression, antihyperlipidemia, antimicrobial, antioxidant activity, antihypertensive }\end{array}$ \\
Antioxidant activity, antidiabetic activity, antimicrobial activity, antitumor activity, antianxiety activity \\
Annona reticulate & $\begin{array}{l}\text { Antipyretic activity, anthelmintic activity, antiulcer activity, antinociceptive activity, antinociceptive } \\
\text { annona squamosa }\end{array}$ \\
Regulation of hyperthyroidism and lipid per oxidation4, analgesic and anti-inflammatory activity, \\
antibacterial and cytotoxic activity, antioxidant and antilipidimic activity, antiulcer activity, hypoglycemic \\
and antidiabetic activity, molluscicidal properties, genotoxic effect, vasorelaxant activity, antitumor \\
activity, hepatoprotective activity, larvicidal activity, insecticidalactivity, anthelmintic activity \\
Antimicrobial activity, antioxidant activity, anti-inflammatory activity, antimalarial activity, in vivo \\
trypanocidal activity, anti-snake venom activity, antinoceptive activity, anthelmintic activity
\end{tabular}

model, the methanolic extract of seeds of $A$. squamosa Linn. shows proliferative effect in regulating hyperthyroidism [73]. A. squamosa leaves shows antiplasmodial activity, while stem bark shows moderate activity in the methanolic extract [74]. A. squamosa Linn. shows abortifacient activities in the seed extract [75]. A squamosa seeds extract shows anthelmintic activity [76]. The bark and leaves possess cytotoxicity, analgesic, anti-inflammatory and antiulcer activities [52].

\section{A. senegalensis $\mathrm{L}$.}

The in vitro cytotoxicity activity of methanol extract of leaves was performed with A2780 ovarian cancer cells. A. senegalensis showed low cytotoxicity with an inhibitory concentration $50 \%$ of $28.8 \mu \mathrm{g} / \mathrm{ml}$. Kaurenoic acid from root bark possesses antiproliferative effect against HeLa and PANC-1 cell lines. A. senegalensis had potent antibacterial activity against Staphylococcus aureus $(62.5 \mu \mathrm{g} / \mathrm{ml})$ and Candida albicans $(250 \mu \mathrm{g} / \mathrm{ml})$. A. senegalensis shows activity against chloroquino resistant strain of Plasmodium falciparum in the root extract. A. senegalensis neutralized lethal toxicity induced by Echis ocellatus venom in the methanol leaf extracts. Flavonoids and tannins are the key phytochemicals mediated the activity. Extracts of the root bark induces the central nervous system depressant effect of phenobarbitone in a dose-dependent fashion. A. senegalensis from Burkina Faso has much better antioxidant activity compared to that from Togo in the leaf extract. This may be due to higher polyphenolic flavonoids in those from Burkina Faso. In vitro hemostatic tests on hydroalcoholic extracts of the leaves, an aporphine alkaloid, (-)-roe merine was identified as active principle responsible for the insecticidal activity. Anticoagulant properties which have 39\% reduction of plasma recalcification time [55]. Table 2 shows the pharmacological activities of Annona species.

\section{CONCLUSION}

The family Annonacae has several pharmacological activities such as antiasthmatic, antidiabetic, anti-inflammatory, antioxidant, antimicrobial, anxiolytic, hypoglycemic activity antidiarrheal, adaptogenic, anthelmintic, antiestrogenic, antimalarial, antiproliferative, antipsoriatic, larvacidal, muscle contractile, hepatoprotective, and anticonvulsant activity. Hexane, ethyl acetate and methanol extracts of Annonacea family (A. muricata, Annona cherimoya, A. reticulata, A. squamosa, and A. senegalensis) contain phytochemical constituents such as sterols, triterpenes, alkaloids, glycosides, saponins, flavonoids, phenolics, and tannins are present. In this review article, effort has been taken to collect and compile the details regarding five species of Annona family which will be useful to the society to venture into a field of alternative systems of medicine.

\section{REFERENCES}

1. Moghadamtousi S, Fadaeinasab M, Nikzad S, Mohan G, Ali H, Kadir H. Annona muricata (Annonaceae): A review of its traditional uses, isolated acetogenins and biological activities. Int J Mol Sci $2015 ; 16: 15625-58$
2. Natural Resources Conservation Service (NRCS). Plants Profile Annona squamosa L. United States: Department of Agriculture; 2008. p. 4-17.

3. Germplasm Resources Information Network (GRIN). Taxonomy for Plants. USDA, ARS, National Genetic Resources Program; 1997. p. 7-11.

4. Wunderlin R, Hansen B. Synonyms of Annona squamosa. Atlas Florida Vasc Plants 2008;4(2):24-7.

5. Kumar AS, Venkatarathanamma V, Saibabu VN. Phytochemical and phytotherapeutic properties of Annona squamosa, Annona reticulata and Annona muricata: A review. Asian J Plant Sci Res 2015;5(8):28-33.

6. Orwa C, Mutua A, Kindt R, Jamnadass R, Anthony S. Agroforestree Database: A Tree Reference and Selection Guide version 4.0. 2009 Available from: http://www.worldagroforestry.org/sites/treedbs/ treedatabases.asp.

7. Adewole SO, Caxton-Martins EA. Morphological changes and hypoglycemic effects of Annona muricata Linn. (Annonaceae) leaf aqueous extract on pancreatic B-cells of streptozotocin-treated diabetic rats. Afr J Biomed Res 2006;9:173-87.

8. Popenoe W. The Cherimoya. California Avocado Society Year Book. Vol. 54. 1970. p. 133-9.

9. Sobiya DR, Jannet JV, Aiyavu C, Panneerselvam K. The hepatoprotective effect of alcoholic extract of Annona squamosa leaves on experimentally induced liver injury in Swiss albino mice. Int J Integr Biol 2009;5(3):182-6.

10. CSIR. The Wealth of India. Raw Materials. Vol. I. A revised edition. New Delhi: Publications and Information Directorate Council of Scientific and Industrial Research; 1985.

11. Chetty KM, Sivaji K, Tulasi Rao K. Flowering Plants of Chittoor district, Andhra Pradesh, India. Vol. 169. Tirupati: Students offset Printers; 2008. p. 201.

12. Palgrave KC. Trees of Southern Africa. Cape Town: Struik Publishers; 2002.

13. Adewole, S, Ojewole J. Protective effects of Annona muricata Linn. (Annonaceae) leaf aqueous extract on serum lipid profiles and oxidative stress in hepatocytes of streptozotocin-treated diabetic rats. Afr J Tradit Complement Altern Med 2009;6:30-41.

14. Wu FE, Gu ZM, Zeng L, Zhao GX, Zhang Y, McLaughlin JL, et al. Two new cytotoxic monotetrahydrofuran Annonaceous acetogenins, annomuricins A and B, from the leaves of Annona muricata. J Nat Prod 1995;58(6):830-6.

15. Sahpaz S, Gonzalez MC, Hocquemiller R, Zafra-Polo MC, Cortes D. Annosenegalin and anagalene: Two cytotoxic monotetrahydrofuran acetogenins from Annona senegalensis and Annona cherimola. Phytochemistry 1996;42(1):103-7.

16. Amoo IA, Emenike AE, Akpambang VO. Compositional evaluation of Annona cherimola (Custard apple) fruit. Trends Appl Sci Res 2008:2:216-20.

17. Himesh S, Akand S, Sarvesh S. Quantification of ascorbic acid in leaves of Annona squamosa. Int J Pharm Pharm Sci 2011;4(3):144-7.

18. Dambatta S, Aliyu B. A survey of major ethno medicinal plants of Kano North, Nigeria, their knowledge and uses by traditional healers. Bayero J Pure Appl Sci 2011;4(2):28-34.

19. Ofukwu R, Ayoola A, Akwuobu C. Medicinal plants used in the management of tuberculosis in humans and animals by Idoma tribe of North Central Nigeria. Niger Vet J 2008;29(2):25-30.

20. Faleyimu O, Ahmad I, Akinyemi O. Herbal approach to the treatment 
of chicken pox: A case study of Giwa local government, Kaduna state. Niger Int J Biomed Health Sci 2010;6(1):13-8.

21. Ahombo G, Ampa R, Diatewa M, Mpati J, Abena A, Ouamba J. Investigating on related diabetes therapeutic plants used in traditional medicine at Brazzaville. J Med Plants Res 2012;6(44):5630-9.

22. Traore MS, Baldé MA, Diallo MS, Baldé ES, Diané S, Camara A, et al. Ethnobotanical survey on medicinal plants used by Guinean traditional healers in the treatment of malaria. J Ethnopharmacol 2013;150(3):1145-53.

23. National Research Council. Custard apples (Annona species). In: Lost Crops of Africa: Vol. III. Washington DC: National Academic Press; 2008. p. 244-6.

24. Goli J, Ogaji O, Tor-Anyin T, Igoli N. Traditional medicine practice amongst the Igede people of Nigeria. Part II. Afr J Tradit CAM $2005 ; 2(2): 134-52$

25. Salifou S, Offoumon O, Gouissi F, Pangui L. Endogenous recipes for controlling arthropod ectoparasites of domestic poultry. Rev Bras Parasitol Vet Jaboticabal 2012;22(1):119-23.

26. Foong CP, Hamid RA. Evaluation of anti-inflammatory activities of ethanolic extract of Annona muricata leaves. Rev Bras Farmacogn 2012;22:6

27. Verma MA, Kumar PA, Kavitha D, Anurag KB. Anti-denaturation and antioxidant activities of Annona cherimola in-vitro. Int J Pharm Biosci 2011;2(2):1-6

28. Chen CY, Wu TY, Chang FR, Wu TC. Lignans and Kauranes from the stems of Annona cherimola. J Chin Chem Soc 1998;45(5):629-34.

29. Wele A, London C, Labbe H, Vovelle F, Zang Y, Bodo B. Sequence and solution structure of cherimolacyclopeptide A and B, novel cyclooctapeptides from the seeds of Annona cherimola. Tetrahedron 2004;60:405-14.

30. Ferreira L, Perestrelo R, Camara JS. Comparative analysis of the volatile fraction from Annona cherimola Mill. Cultivars by solid phase micro extraction and gas chromatography-quadrupole mass spectrometry detection. Talanta 2009;77:1087-96.

31. Rani DJ, Devi RR, Shri MV. Phytochemical screening and antimicrobial activity of various solvent extracts of Annona reticulata leaves. IJSIT 2013;2(5):347-58

32. Yang TH, Chi-Ming C. Structure of squamolone, a novel diazepine from Annona squamosa L. J Chin Chem Soc (Taipei) 1972;19:149-51

33. Chang FR, Chen JL, Chiu HF, Wu MJ, Wu YC. Acetogenins from seeds of Annona reticulata. Phytochemistry 1998;47(6):1057-61.

34. Maeda U, Hara N, Fujimoto Y, Shrivastava A, Gupta YK, Sahai M. $\mathrm{N}$-fatty acyl tryptamines from Annona reticulata. Phytochemistry 1993;34:1633-5

35. HishamA, Sunitha C, Sreekala U, Pieters L, Bruyne DT, Heuvel VH, et al. Reticulacinone, an acetogenin from Annona reticulata. Phytochemistry 1994:35:1325-9.

36. Etse JT, Waterman PG. Chemistry in the Annonaceae, XXII: 14-Hydroxy-25-desoxyrollinicin from the stem bark of Annona reticulata. J Nat Prod 1986;49:684-6.

37. Saad JM, Hui YH, Rupprecht JK, Anderson JE, Kozlowski JF, Zhao GX, et al. Reticulatacin: A new bioactive acetogenin from Annona reticulate (Annonaceae). Tetrahedron 1991;47:2751-6.

38. Awa EP, Ibrahim S, Ameh DA. GC/MS analysis and antimicrobial activity of diethyl ether fraction of methanolic extract from the stem bark of Annona senegalensis pers. IJPSR 2012;3(11):4213-8.

39. Pandey N, Barve D. Phytochemical and pharmacological review on Annona squamosa Linn. Int J Res Pharm Biomed Sci 2011;2:2229-3701.

40. Lapornik B, Prosek M, Wondra AG. Comparison of extracts prepared from plant by-products using different solvents and extraction time. J Food Eng 2005;71:214-22.

41. Yisa J, Egila J, Darlinton A. Chemical composition of Annona senegalensis from Nupe land, Nigeria. Afr J Biotech 2010;9(26):4106-9.

42. Ogunlesi M, Okiei W, Ofor E, Awonuga O. Determination of the concentrations of zinc and vitamin $\mathrm{C}$ in oysters and some medicinal plants used to correct male factor infertility. J Nat Prod 2009;2:89-97.

43. Okoye TC, Akah PA, Okoli CO, Ezike AC, Omeje EO, Odoh UE. Antimicrobial effects of a lipophilic fraction and Kaurenoic acid isolated from the root bark extracts of Annona senegalensis. Evid Based Complement Alter Med 2012;25-34.

44. Philipov S, Kande KM, Machev K. Alkaloids of Annona senegalensis. Fitoterapia 1995 66:275-6.

45. Bamba PD, Abalansard G, Maillard C, Demenil G, Gayte-Sorbier A. Characterization of amino acids in the stem bark of Annona senegalensis Pers. Plante Med Phytother 1984;18:36-45.

46. Mackie A, Misra AL. Chemical investigation of the leaves of Annona senegalensis and constituents of the leaf wax. J Sci Food Agric
1956;7:203.

47. Ekundayo O, Oguntimein B. Composition of the essential oils of Annona senegalensis Var. Senegalensis. Plant Med 1986;52:202-4.

48. Adesogan EF, Durodola JI. Antitumor and antibiotic principles of Annona senegalensis. Phytochemistry 1976;15:1311-2.

49. Pourmorad F, Hosseininelir SJ, Shahabimajd N. Antioxidant activity, phenol and flavonoid content of some selected Iranian medicinal plants. Afr J Biotechnol 2006;5:1142-5.

50. Okechukwu PC, Okwesili FC, Parker EJ, Abubakar B, Emmanuel CO, Christian EO. Phytochemical and acute toxicity studies of Moringa oleifera ethanol leaf extract. Int J Life Sci Biotechnol Pharm Res 2013;2(2):66-71.

51. Rice-Evans CA, Miller NJ, Bolwell PG, Bramley PM, Pridham JB. Therelative activities of plant-derived polyphenolic flavonoid. Free Radical Res 1995;22:375-83.

52. Jyothi BA, Venkatesh K, Chakrapani P, Rani AR. Phytochemical and pharmacological potential of Annona cherimola-A review. Int $\mathrm{J}$ Phytomed 2011;3:439-47.

53. Sovia E, Ratwita W, Wijayanti D, Novianty DR. Hypoglycemic and hypolipidemic effects of Annona muricata L. leaf ethanol extract. Int J Pharm Pharm Sci 2017;9(3):170-4.

54. Roa R, Babu M, Rao MR. Saponins as anti-carcinogens. J Nutr 1995:125:717-24.

55. Okhale S, Akpan E, Fatokun OT, Eseivo KB, Esievo B, Kunle OF. Annona senegalensis Persoon (Annonaceae): $\mathrm{A}$ review of its ethnomedicinal uses, biological activities and phytocompounds. J Pharmacogn Phytochem 2016;5(2):211-9.

56. Baskar R, Rajeswari V, Kumar TS. In vitro antioxidant studies in leaves of Annona species. Indian J Exp Biol 2007;45(5):480-5.

57. Yuan SS, Chang HL, Chen HW, Yeh YT, Kao YH, Lin KH, et al. Annonacin, a mono-tetrahydrofuran acetogenin, arrests cancer cells at the G1 phase and causes cytotoxicity in a Bax- and caspase-3-related pathway. Life Sci 2003;72(25):2853-61.

58. Yuan SS, Chang HL, Chen HW, Kuo FC, Liaw CC, Su JH, et al. Selective cytotoxicity of squamocin on T24 bladder cancer cells at the S-phase via a Bax-, Bad, and caspase-3-related pathways. Life Sci 2006;78(8):869-74.

59. Suresh HM, Shivakumar B, Shivakumar SI. Inhibitory potential of the ethanol extract of Annona reticulata Linn against melanoma tumor. J Nat Pharm 2011;2:168-72.

60. Mondal S, Mondal N, Mazumder U. In vitro cytotoxic and human recombinant caspase inhibitory effect of Annona reticulata leaves. Indian J Pharmacol 2007;39:253-4.

61. Kaleem M, Asif M, Ahmed QU, Bano B. Antidiabetic and antioxidant activity of Annona squamosa extract in streptozotocin-induced diabetic rats. Singapore Med J 2006;47(8):670-5.

62. Thang TD, Kuo PC, Huang GJ, Hung NH, Huang BS, Yang ML. Chemical constituents from the Leaves of Annona reticulata and their inhibitory effects on no production. Molecules 2013;18:4477-86.

63. Rout SP, Kar DM, Mohapatra SB, Swain SP. Anti-hyperglycemic effect Annona reticulata L. leaves on experimental diabetic rat model. Asian J Pharm Clin Res 2013;6(1):56-60.

64. Madhuri S, Pandey G. Some anticancer medicinal plants of foreign origin. Curr Sci 2009;96:779-83.

65. Shirwaikar A, Rajendran K, Kumar CD, Bodla R. Antidiabetic activity of aqueous leaf extract of Annona squamosa in streptozotocinnicotinamide Type 2 diabetic rats. J Ethnopharmacol 2004;91(1):171-5.

66. Padhi LP, Panda SK, Satapathy SN, Dutta SK. In vitro evalution of antibacterial potential of Annona squamosa Linn. and Annona reticulata L. from Simlipal biosphere reserve, Orissa, India. J Agric Technol 2011;7(1):133-42.

67. Pardhasaradhi BV, Reddy M, Mubarak AA, Kumari AL, Khar A. Antitumour activity of Annona squamosa seed extracts is through the generation of free radicals and induction of apoptosis. Indian J Biochem Biophys 2004;41:167-72

68. Ashok K, Pardhasaradhi BV, Madhurima R, Mubarak AA, Leela AK. Differential cytotoxic effects of Annona squamosa seed extracts on human tumour cell lines: Role of reactive oxygen species and glutathione. J Biosci 2005;30(2):237-44.

69. Suresh K, Mamoharan S, Panjamurthy K, Kavitak K. Chemopreventive and antilipidperoxidative efficiency of Annona squamosa bark extract. Pak J Biol Sci 2006;9(14):2600-5.

70. Mohamed TS, Madhusudana CC, Ramkanth S, Rajan VS, Mahesh KK, Gauthaman K. Hepatoprotective herbs- A review. Int J Res Pharm Sci 2010;1(1):1-5.

71. Joseph MJ, Ester I, Joseph ON. Mosquito larvicidal and cytotoxic activities of 3 Annona species and isolation of active principles. J Med 
Plant Res 2009;3(9):674-80

72. Ekramul H, Motiur R, Ekramul MI, Parvin MS. Pesticidal activity of pure compound annotemoyin-1 isolated from chloroform extract of the plant Annona squamosa Linn. Against Tribolium castaneum (Herbst). Pak J Biol Sci 2003;6(12):1088-91.

73. Panda S, Kar A. Annona squamosa seed extract in the regulation of hyperthyroidism and lipid-peroxidation in mice: Possible involvement of quercetin. Phytomedicine 2007;14(12):799-805.
74. Ahir A, Satti GM, Khalid SA. Antiplasmodial activity of selected Sudanese medicinal plants with emphasis on Maytenus senegalensis (Lam.) Exell J Ethnopharmacol 1999;64(3):227-33.

75. Mishar A, Dogra JV, Singh JN, Jha OP. Post-coital antifertility activity of Annona squamosa and Ipomoea fistulosa. Planta Med 1979;35(3):283-5.

76. Souza MC, Bevilaqa CM, Morais SM, Cicero TC. Anthelmintic acetogenin from Annona squamosa L. seeds. Annu Brazil Acad Sci 2008;80(2):271-7. 